\title{
Expression and Characterization of Transforming Growth Factor $\alpha$ Precursor Protein in Transfected Mammalian Cells
}

\author{
LARRY E. GENTRY,${ }^{1}{ }^{+*}$ DANIEL R. TWARDZIK, ${ }^{1}$ G. JONATHAN LIM, ${ }^{1}$ JANE E. RANCHALIS, ${ }^{1}$ \\ AND DAVID C. LEE ${ }^{2}$ \\ Oncogen, Seattle, Washington $98121,{ }^{1}$ and Department of Microbiology and Immunology and Lineberger Cancer \\ Research Center, University of North Carolina, Chapel Hill, North Carolina $27514^{2}$
}

Received 10 November 1986/Accepted 26 January 1987

\begin{abstract}
Analysis of a cDNA clone derived from retrovirus-transformed rat fibroblasts has recently suggested that the mature 50-amino-acid form of transforming growth factor $\alpha$ (TGF $\alpha)$ is derived from a 159-amino-acid transmembrane precursor by proteolytic cleavage. To understand the processing of the TGF $\alpha$ precursor molecule in more detail, we have expressed this protein in baby hamster kidney (BHK) fibroblasts under control of the metal-ion-inducible metallothionein promoter and characterized the expressed precursor with site-specific antipeptide antibodies. One of the BHK transfectants, termed 5:2, expressed the TGF $\alpha$ mRNA in a cadmium- and zinc-inducible manner. The TGF $\alpha$ precursor protein was detected by immunoprecipitation analysis of radiolabeled cell cultures. In the induced 5:2 cells, a polypeptide of $M_{r} 13,000$ to 17,000 was readily identified by peptide antisera made to three difierent regions of the TGF $\alpha$ precursor protein. No such protein species were observed in BHK cells treated with cadmium and zinc or in uninduced 5:2 cells. However, two cell lines known to produce TGF $\alpha$ naturally, Leydig testicular tumor cells and Snyder-Theilan feline sarcoma virus-transformed Fisher rat embryo fibroblasts, possessed detectable levels of immunologically related $M_{\mathbf{r}}$ 13,000 to 17,000 proteins. Cell fractionation studies indicate that the $M_{\mathrm{r}} 13,000$ to 17,000 species expressed in induced 5:2 cells is membrane associated, consistent with predictions based on the cDNA sequence of the TGF $\alpha$ precursor. Media conditioned by induced 5:2 cells contained epidermal growth factor receptor-competing activity, which, upon size fractionation, was similar in size to the mature processed form of TGF $\alpha$. These data show that these nontransformed BHK cells possess the ability to process the TGF $\alpha$ precursor molecule into its native form.
\end{abstract}

Transforming growth factor $\alpha(\mathrm{TGF} \alpha)$ is a small polypeptide, of approximately 50 amino acids, which appears to be structurally and functionally related to epidermal growth factor (EGF) $(15,16)$. These polypeptides show significant sequence homology and appear to have evolved by gene duplication from a common ancestral molecule (15). TGF $\alpha$ and EGF compete for binding to the same cell surface receptor, the EGF receptor, and activate the associated tyrosine kinase activity of the receptor molecule $(17,18)$. Although these growth factors are potent mitogens in tissue culture, recent reports have suggested that TGF $\alpha$ may have different biological properties from those of EGF. TGF $\alpha$ has been reported to be more potent at promoting calcium release from rat fetal long bones $(6,7)$ and as an angiogenesis factor (20).

TGF $\alpha$, initially identified in the medium of retrovirustransformed rodent cells $(1,26,27$; for reviews, see reference 24 and D. R. Twardzik and J. R. Ranchalis, UCLA Symp. Bone Cartilage, in press), is expressed in a variety of human tumors and tumor cell cultures $(16,23)$ and is thought to play a role in the malignancy process. Analysis of the cloned TGF $\alpha$ cDNA has revealed some interesting features regarding its expression. As is true of several other growth factors, TGF $\alpha$ appears to be processed from a larger precursor molecule. In the rat and the human, the precursors are

\footnotetext{
* Corresponding author.

$\dagger$ Present address: Department of Biochemistry, Medical College of Ohio, Toledo, OH 43699.
}

159 and 160 amino acids, respectively, and each contains a typical leader sequence and an extremely hydrophobic domain resembling a transmembrane region $(2,11)$. This led to the prediction that the mature 50-amino-acid form of TGF $\alpha$ is derived by proteolytic release from a membrane-bound precursor molecule. Of particular interest is the finding that proteolysis occurs at unique Ala-Val-Val sequences and is most probably mediated by a protease having elastase-type specificity (11; D. C. Lee, T. M. Rose, N. R. Webb, D. R. Twardzik, J. R. Ranchalis, H. Marquardt, and G. J. Todaro, Perspect. Med. [R. Soc. Lond. Symp.], in press). The fact that an unusual protease is involved in the processing of the precursor raises the possibility that proteolysis is a regulatory event in the generation of the mature growth factor. Moreover, the marked sequence conservation of the entire precursor that is evident in a comparison of the human and rat cDNAs may suggest that the precursor has functions distinct from those of the mature growth factor.

To understand the structure and processing of the TGF $\alpha$ precursor in more detail, we have constructed an expression vector that places a portion of the rat TGF $\alpha$ CDNA which encodes the complete TGF $\alpha$ precursor molecule under the control of the inducible mouse metallothionein promoter. This construct has been introduced into baby hamster kidney (BHK) fibroblasts, and the precursor protein produced in these cells has been characterized with site-specific antipeptide antibodies. Our results demonstrate that the TGF $\alpha$ precursor is a membrane-associated polypeptide with $M_{\mathrm{r}} 13,000$ to 17,000 that is proteolytically processed in $\mathrm{BHK}$ 
fibroblasts to release a mature $M_{\mathrm{r}} 6,000 \mathrm{TGF} \alpha$ form into the culture medium.

\section{MATERIALS AND METHODS}

Cell culture and radioactive labeling. Fisher rat embryo fibroblast (FRE) cells and their Snyder-Theilen feline sarcoma virus-transformed counterparts were from previously described clones (27). Leydig testicular tumor cells were generously provided by Greg Mundy. BHK fibroblasts were provided by Richard Palmiter. Leydig tumor cells were grown in RPMI 1640 supplemented with $15 \%$ fetal bovine serum. All other cells were grown in Dulbecco modified Eagle medium containing $10 \%$ fetal bovine serum.

Confluent cultures of cells were labeled with ${ }^{35}$ S $]$ cysteine $(>1,000 \mathrm{Ci} / \mathrm{mmol}$; New England Nuclear Corp.) in cysteinefree Dulbecco modified Eagle medium containing 5\% dialyzed fetal bovine serum. FRE, ST-FeSV-transformed FRE, and Leydig tumor cells were labeled at $500 \mu \mathrm{Ci} / \mathrm{ml}$. For experiments involving BHK cells or the 5:2 transfectants, cells were induced with $2 \mu \mathrm{M}$ cadmium sulfate and $100 \mu \mathrm{M}$ zinc chloride prior to being labeled. Following a $6-$ to $10-\mathrm{h}$ induction period, cells received cysteine-free DME supplemented with $5 \%$ dialyzed fetal bovine serum, $200 \mu \mathrm{Ci}$ of $\left[{ }^{35} \mathrm{~S}\right]$ cysteine per $\mathrm{ml}$, and an equivalent amount of metal ion inducer.

Construction of the metallothionein-rat TGF $\alpha$ plasmid. The TGF $\alpha$ expression vector, was constructed by using plasmid EV142 (13), which contains the mouse metallothionein 1 promoter fused to the $3^{\prime}$ untranslated region of the human growth hormone gene (kindly provided by Richard Palmiter). The mouse metallothionein 1 sequence is contained in an 800-base-pair (bp) fragment which extends from the 5 ' flanking sequence through the promoter and includes the first 64 bp of exon 1 . This fragment is fused by a unique $B g I I I$ site to a 625 -bp human growth hormone fragment which contains the $3^{\prime}$ untranslated region of exon 5 , the polyadenylation signal, and 3 ' flanking sequences. These fragments are contained in pBX322, a high-copy-number derivative of pBR322 which contains an XhoI linker at about position 3000 . To generate $\mathrm{pEV} 2$, a 700-bp SmaI fragment which includes the entire rat TGF $\alpha$ coding region was inserted into the unique $B g$ III site. Clones with the proper orientation were selected, and DNA was isolated for transfection.

Transfection of BHK cells. Subconfluent BHK cells grown in $100-\mathrm{mm}$ dishes containing $10 \mathrm{ml}$ of complete medium (Dulbecco modified Eagle medium with $10 \%$ fetal bovine serum) were transfected with $20 \mu \mathrm{g}$ of pEV2 as a calcium phosphate precipitate (28) in the presence of $1 \mathrm{mM}$ chloroquine. After the cells had been incubated for $5 \mathrm{~h}$ at $37^{\circ} \mathrm{C}$, the medium was removed and replaced with $10 \mathrm{ml}$ of fresh medium. After an additional $24 \mathrm{~h}$ in culture, Geneticin (G418; GIBCO Laboratories) was added to the medium at $500 \mu \mathrm{g} / \mathrm{ml}$. Antibiotic-resistant clones were visible after 1 week; these clones were isolated and tested for their expression of TGF $\alpha$ mRNA by a solution hybridization assay (D. C. Lee, K. J. Ibbotson, S. M. D'Souza, C. Reasner, G. Carpenter, D. R. Twardzik, G. J. Todaro, and G. R. Mundy, J. Clin. Invest., in press).

RNA isolation and Northern blot analysis. RNA was isolated by homogenization of tissue or cells in $4 \mathrm{M}$ guanidine thiocyanate and sedimentation through $5.7 \mathrm{M} \mathrm{CsCl} \mathrm{(5).}$ Northern blots were performed essentially as described previously (10) with poly(A) ${ }^{+}$RNA selected by chromatography on oligo(dT)-cellulose.
Production of antipeptide antibodies. Peptides were synthesized by solid-phase techniques on a Beckman automated instrument (4) and purified by preparative high-pressure liquid chromatography. The composition of the peptides was confirmed by amino acid analysis. Purified peptides were coupled to bovine $\gamma$-globulin through the cysteine residue and used to immunize New Zealand White rabbits (3). Immunization schedules were as described previously (3).

Immunoprecipitation analysis. Radiolabeled cell cultures were lysed in detergent-containing buffer (20 $\mathrm{mM}$ Tris hydrochloride [pH 7.4], $150 \mathrm{mM} \mathrm{NaCl}, 0.5 \%$ sodium deoxycholate, $1.0 \%$ Nonidet P-40, $1 \mathrm{mM}$ EDTA, $2 \mathrm{mM}$ phenylmethysulfonyl fluoride, 200 kallikrein inhibitory units of aprotinin [Sigma Chemical Co.] per $\mathrm{ml}$ ) and clarified by centrifugation at $100,000 \times g$ for $30 \mathrm{~min}$ at $4^{\circ} \mathrm{C}$. A $100-\mu l$ portion of lysate equivalent to $5 \times 10^{5}$ to $1 \times 10^{6}$ cells was precleared with $10 \mathrm{mg}$ of Staphylococcus aureus and then incubated with $5 \mu \mathrm{l}$ of serum at $0^{\circ} \mathrm{C}$ for $1 \mathrm{~h}$. Immunocomplexes were collected on $S$. aureus and washed as described previously (3). Peptide-blocking experiments were performed with purified peptide. Immunoprecipitated samples were lysed with sodium dodecyl sulfate (SDS)-containing buffer and electrophoresed on $15 \%$ polyacrylamide or 12 to $20 \%$ gradient polyacrylamide gels (9). Radiolabeled proteins were detected by fluorography with $\mathrm{En}^{3} \mathrm{Hance}$ (New England Nuclear).

Radioreceptor assay. The binding of ${ }^{125}$ I-labeled EGF to its receptor was measured on monolayers of Formalin-fixed A431 cells as previously described (1). Concentrations of TGF $\alpha$ are expressed as nanogram equivalents of EGF, i.e., the amount required to produce an inhibition of ${ }^{125} \mathrm{I}$-labeled EGF binding equivalent to that produced by a known amount of EGF.

Membrane fractionation. Radiolabeled cell cultures were collected by scraping. Cells were swollen in hypotonic lysis buffer ( $20 \mathrm{mM}$ HEPES [ $N$-2-hydroxyethylpiperazine- $N^{\prime}-2$ ethanesulfonic acid; $\mathrm{pH}$ 6.9], $1 \mathrm{mM}$ EDTA, $2 \mathrm{mM}$ phenylmethylsulfonyl fluoride, 200 kallikrein inhibitory units of aprotin per ml) at $2 \times 10^{7}$ cells per $\mathrm{ml}$ for $20 \mathrm{~min}$ at $4^{\circ} \mathrm{C}$ and Dounce homogenized. Nuclei and unbroken cells were removed by centrifugation at $2,000 \times g$ for $15 \mathrm{~min}$ at $4^{\circ} \mathrm{C}$, and the supernatant was further fractionated into pelleting (P100) and supernatant (S100) fractions by centrifugation at 100,000 $\times g$. The P100 fraction was separated on discontinuous sucrose gradients essentially as described previously (14). For immunoprecipitation analysis, samples were adjusted to $1 \times$ in detergent lysis buffer.

\section{RESULTS}

Expression of rat TGF $\alpha$ in BHK cells. To characterize the TGF $\alpha$ precursor, we prepared an expression vector ( $\mathrm{pEV} 2$; Fig. 1A) that places the rat TGF $\alpha$ cDNA under the control of the inducible mouse metallothionein I promoter. Induced transcription of this vector would yield a hybrid mRNA of 1 kilobase pair (kb) containing 700 base pairs (bp) of TGF $\alpha$ cDNA, 64 bp of metallothionein gene, and $240 \mathrm{bp}$ of the human growth hormone segment. The last of these was present to provide a $3^{\prime}$ noncoding sequence and polyadenylation signal. pEV2 was cotransfected into BHK cells along with the selectable neomycin resistance marker, and cells resistant to G418 were isolated. Expression of TGF $\alpha$ mRNA in transfected BHK cells was determined by solution hybridization as described previously (10). One transfectant (termed 5:2) was shown to express the hybrid TGF $\alpha$ mRNA at high levels following induction with cadmium and zinc and was used for further characterization. 

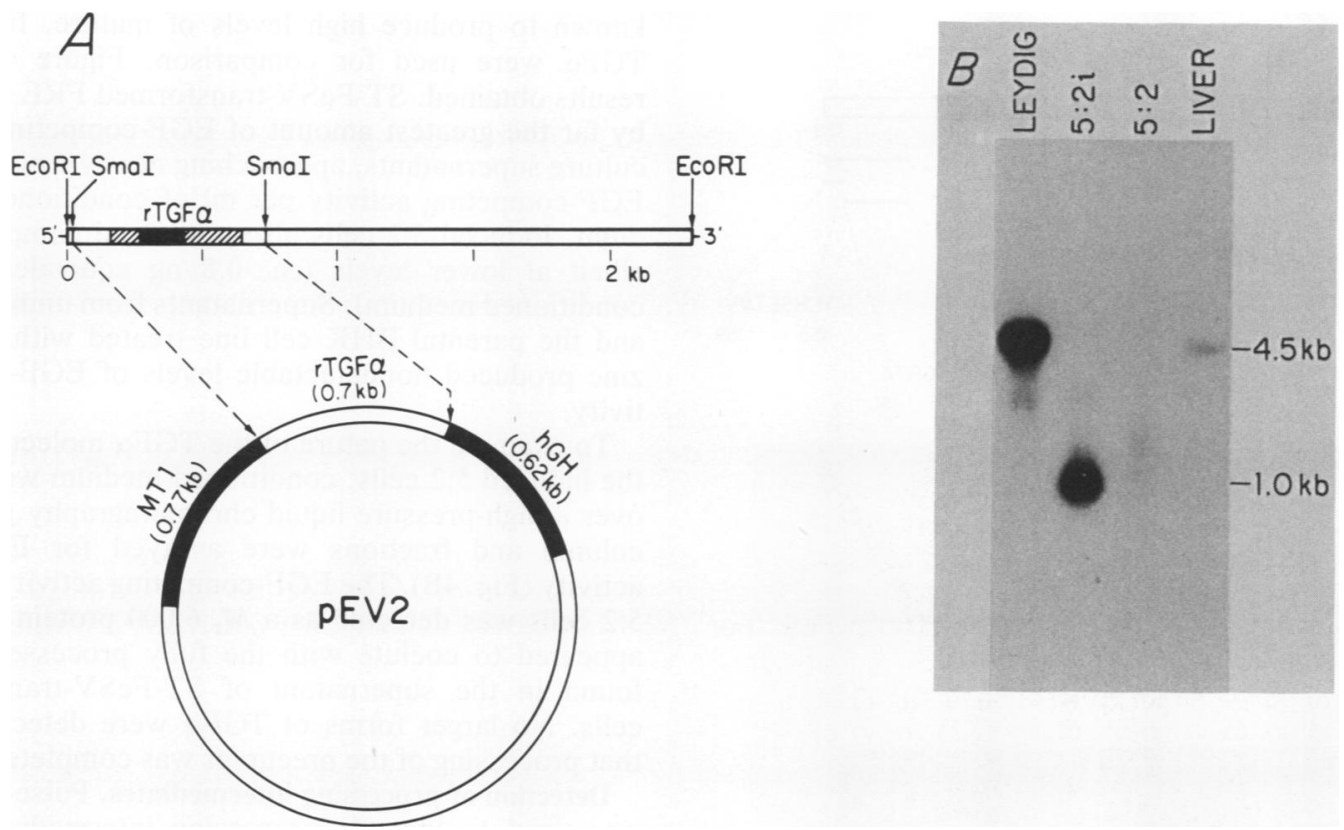

FIG. 1. (A) Schematic diagram showing construction of the expression vector pEV2. A 700-bp SmaI fragment of the rat TGF $\alpha$ cDNA which contains the entire coding region for the TGF $\alpha$ precursor protein (שs and $س$ ) was inserted behind the mouse metallothionein promoter element (MT1). A 620-bp fragment containing the $3^{\prime}$ end of human growth hormone gene (hGH) [including the poly(A) addition sequence] was joined to the $3^{\prime}$ end of the rat TGF $\alpha$ cDNA fragment. (B) Northern blot analysis of poly(A) ${ }^{+}$RNA with the rat TGF $\alpha$ cDNA probe. Poly $(A)^{+}$RNA (5 $\mu$ g) from Leydig testicular tumor cells, normal rat liver, uninduced 5:2 cells (5:2), and 5:2 cells treated with cadmium and zinc (5:2i) were electrophoresed on a $1 \%$ agarose-formaldehyde gel and blotted onto nitrocellulose. Hybridization and washing conditions are described in Materials and Methods.

A Northern blot analysis of poly $(\mathrm{A})^{+}$RNA isolated from 5:2 cells is shown in Fig. 1B. Equivalent amounts of poly(A) ${ }^{+}$RNA from rat liver and Leydig testicular tumor cells, a cell line known to produce TGF $\alpha$ protein, were included for comparison. Induced 5:2 cells contained a large amount of 1-kb mRNA that hybridized to the TGF $\alpha$ cDNA probe. The levels of this hybrid 5:2 mRNA appeared to be similar to, if not greater than, the levels observed for the natural 4.5-kb mRNA found in Leydig cells. In contrast, uninduced 5:2 cells contained nondetectable amounts of TGF $\alpha$ mRNA. Using the solution hybridization assay, we estimated that the hybrid TGF $\alpha$ mRNA was induced at least 20 - to 50-fold in 5:2 cells after a 10- to 12-h exposure to cadmium and zinc.

Immunoprecipitation of the TGF $\alpha$ precursor polypeptide with site-specific antipeptide antibodies. Site-specific antibodies directed toward peptide sequences within the predicted rat TGF $\alpha$ precursor protein molecule (11) were generated in rabbits by using synthetic peptides as immunogens. Figure 2A shows the peptide sequences which were used, as well as their relative locations within the TGF $\alpha$ precursor polypeptide. The TGF $\alpha$ antibodies were directed toward epitopes present within the carboxy-terminal region of the precursor molecule and are precursor specific.

Antisera were tested for their ability to specifically immunoprecipitate induced proteins from $\left[{ }^{35} \mathrm{~S}\right]$ cysteine-labeled cell cultures. The results of the immunoprecipitation analysis are shown in Fig. 2B. In the cadmium- and zinc-induced 5:2 cells (lanes 5:2i), prominently labeled proteins of $M_{\mathrm{r}}$ 13,000 to 17,000 were readily identified by each of the peptide antisera. This species was not identified by normal rabbit serum and was not immunoprecipitated from control BHK cells exposed to similar levels of cadmium and zinc (lanes BHK) or in uninduced 5:2 cells (lanes 5:2). Further- more, incubation of peptide antisera with synthetic peptide immunogen prior to addition of radiolabeled cell lysate completely abolished detection of this protein species (lane 5:2i+PEP). Two additional TGF $\alpha$ antisera, one directed against a 17-amino-acid synthetic peptide constituting the carboxy-terminus of the fully processed TGF $\alpha$ (12) and one generated against the synthetic 50-amino-acid TGF $\alpha$ molecule, identified proteins which comigrated with the $M_{\mathrm{r}} 13,000$ to 17,000 species recognized by the precursor-specific antibodies (data not shown).

SDS-polyacrylamide gel electrophoresis of immunoprecipitates from $\left[{ }^{35} S\right]$ cysteine-labeled FRE, ST-FeSVtransformed FRE, and Leydig testicular tumor cells are shown in Fig. 3. Both transformed cell types, known to produce TGF $\alpha$ naturally, exhibited an immunoreactive protein species which appeared to comigrate with the species observed in 5:2 cells. This $M_{\mathrm{r}} 13,000$ to 17,000 protein was identified by two different TGF $\alpha$ antisera and in a peptidespecific manner. Furthermore, this protein was not detected in the nontransformed FRE cells. These results provide strong evidence that the $M_{\mathrm{r}} 13,000$ to 17,000 species identified in the BHK transfectants and in the ST-FeSVtransformed FRE and Leydig cell lines is the TGF $\alpha$ precursor and are consistent with the size $\left(M_{\mathrm{r}} 16,970\right)$ of the precursor molecule predicted on the basis of the cloned cDNA sequence (11). Interestingly, the $M_{\mathrm{r}} 13,000$ to 17,000 TGF $\alpha$ precursor polypeptide appeared more abundant in the transfectant BHK cell line than in either ST-FeSVtransformed FRE or Leydig cells.

In addition to the $M_{\mathrm{r}} 13,000$ to 17,000 protein species identified in ST-FeSV-transformed FRE and Leydig tumor cells, a protein of $M_{\mathrm{r}} 25,000$ was detected in the immunoprecipitates. This protein was present in both transformed cell types, was absent from nontransformed FRE cells, and 

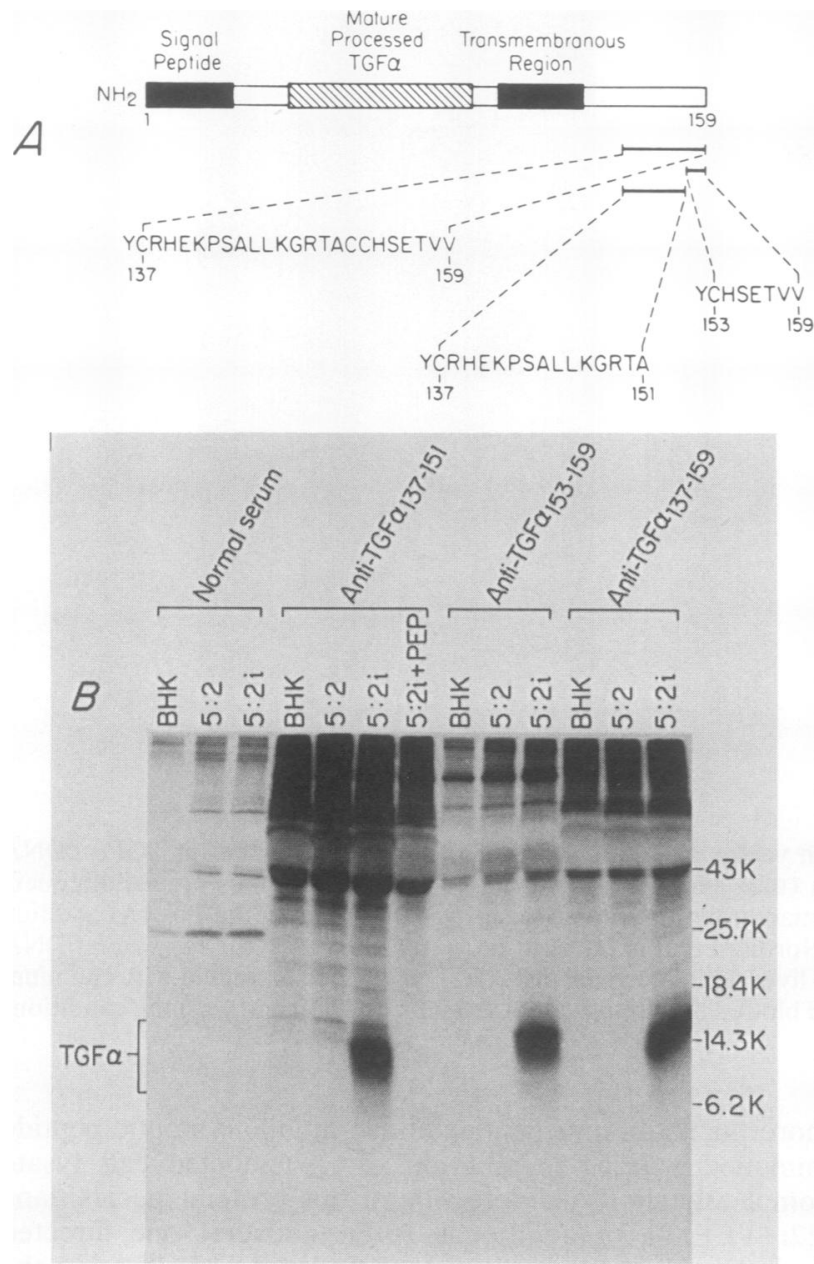

FIG. 2. (A) Line diagram of the rat TGF $\alpha$ precursor protein, showing the location and sequences of synthetic peptide immunogens. Symbols: $\mathbf{m}, \mathbf{m}$, functionally important regions of the precursor. (B) Gel electrophoresis of immunoprecipitates prepared from antipeptide antibodies. Immunoprecipitates prepared from $\left[{ }^{35} \mathrm{~S}\right]$ cysteine-labeled cells were fractionated on 12 to $20 \%$ polyacrylamide gradient gels and fluorographed. Cells were induced with metal ions for $8 \mathrm{~h}$ and labeled for $12 \mathrm{~h}$ with $\left[{ }^{35} \mathrm{~S}\right]$ cysteine. Antisera used are indicated at the top of the figure. Lanes: BHKi, BHK cells treated with cadmium and zinc; $5: 2$, uninduced $5: 2$ cells; 5:2i, 5:2 cells treated with cadmium and zinc; $5: 2 \mathrm{i}+$ PEP, antibody was blocked with $0.2 \mu \mathrm{g}$ of synthetic peptide immunogen prior to immunoprecipitation analysis of induced 5:2 cells. Molecular mass markers are indicated on the right.

appeared to be identified in a peptide-specific manner. This larger species may be related to higher-molecular-weight forms of bioactive TGF $\alpha$ secreted by some tumor cell lines (12). Alternatively, this polypeptide may represent an immunologically distinct form associated with the $M_{\mathrm{r}} 13,000$ to $17,000 \mathrm{TGF} \alpha$ precursor during immunoprecipitation. The $M_{\mathrm{r}}$ 25,000 form was not detected in the transfected BHK cells.

The TGF $\alpha$ precursor protein is proteolytically processed in BHK cells. To determine whether the TGF $\alpha$ precursor protein was secreted or processed in the transfected BHK cells, conditioned medium was collected from these cells and analyzed for its ability to compete with iodinated EGF for binding to the EGF receptor. As controls, we included the parental BHK cells exposed to cadmium and zinc, as well as the uninduced 5:2 cells. ST-FeSV-transformed FRE cells known to produce high levels of mature, fully processed TGF $\alpha$ were used for comparison. Figure $4 \mathrm{~A}$ shows the results obtained. ST-FeSV-transformed FRE cells produced by far the greatest amount of EGF-competing activity into culture supernatants, approaching nearly $6 \mathrm{ng}$ equivalents of EGF-competing activity per $\mathrm{ml}$ of conditioned culture medium. Induced 5:2 cells also contained competing activity, albeit at lower levels (ca. $0.8 \mathrm{ng}$ equivalents per $\mathrm{ml}$ of conditioned medium). Supernatants from uninduced 5:2 cells and the parental BHK cell line treated with cadmium and zinc produced nondetectable levels of EGF-competing activity.

To examine the nature of the TGF $\alpha$ molecule secreted by the induced 5:2 cells, conditioned medium was fractionated over a high-pressure liquid chromatography gel permeation column and fractions were assayed for EGF-competing activity (Fig. 4B). The EGF-competing activity induced from 5:2 cells was detected as a $M_{\mathrm{r}} 6,000$ protein species which appeared to coelute with the fully processed TGF $\alpha$ form found in the supernatant of ST-FeSV-transformed FRE cells. No larger forms of TGF $\alpha$ were detected, indicating that processing of the precursor was complete in these cells.

Detection of processing intermediates. Pulse-chase analysis was used to identify processing intermediates of TGF $\alpha$. Induced 5:2 cells were pulse-labeled in cysteine-free media for $15 \mathrm{~min}$ with $\left[{ }^{35} \mathrm{~S}\right]$ cysteine and chased with complete media for various times. Detergent lysates were prepared, and the TGF $\alpha$ precursor was immunoprecipitated with antiTGF $\alpha_{137-159}$. Figure 5 shows the results obtained from SDSpolyacrylamide gel electrophoresis of the immunoprecipitates. The TGF $\alpha$ precursor was readily identified in the induced 5:2 cells by using a 15-min labeling period. At time zero, the TGF $\alpha$ precursor behaved as a polypeptide migrating on SDS-polyacrylamide gels with $M_{\mathrm{r}} 14,000$ to 18,000 . After a 20-min chase, an increase in the size of the TGF $\alpha$ precursor polypeptide from $M_{\mathrm{r}} 14,000$ to 18,000 to $M_{\mathrm{r}} 15,000$ to 19,000 was readily apparent. Longer chase times revealed the dramatic decrease in size of the $M_{\mathrm{r}} 15,000$ to 19,000

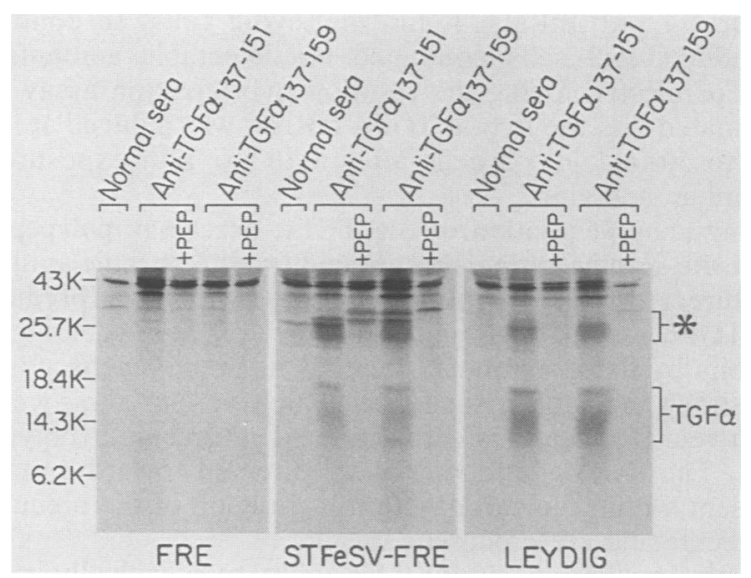

FIG. 3. Immunoprecipitation of TGF $\alpha$ from Leydig testicular tumor and ST-FeSV-transformed FRE cells with precursor-specific antipeptide antibodies. Confluent cultures of cells were labeled for 2 $\mathrm{h}$ with $0.5 \mathrm{mCi}$ of $\left[{ }^{35} \mathrm{~S}\right]$ cysteine per $\mathrm{ml}$ in cysteine-free media. Immunoprecipitates from equivalent amounts of ${ }^{35} \mathrm{~S}$-labeled proteins were prepared and analyzed by SDS-polyacrylamide gel electrophoresis on $15 \%$ polyacrylamide gels. Molecular mass markers (kilodaltons) are shown to the left. + PEP denotes lanes which were preincubated with synthetic peptide prior to immunoprecipitation. Only the bottom two-thirds of the gel is shown. 
$A$

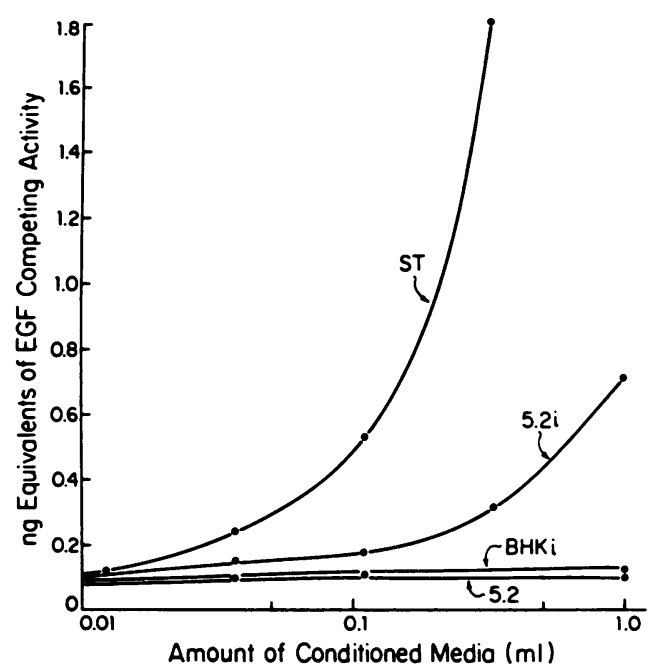

$B$

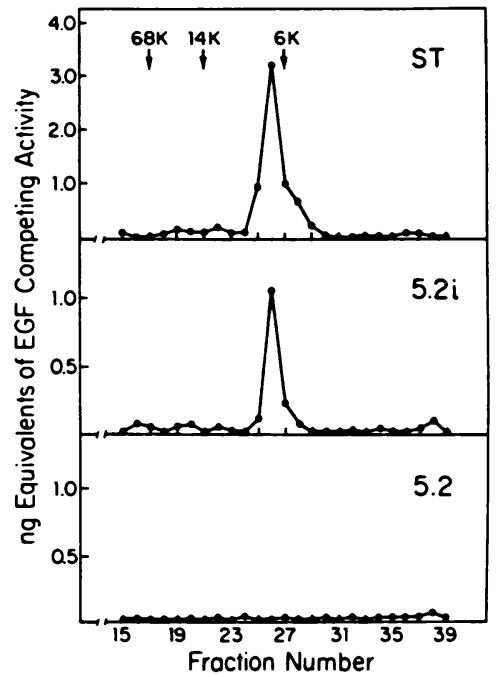

FIG. 4. (A) EGF-competing activity of conditioned medium from tissue culture cells. Conditioned medium prepared as described in Materials and Methods was tested for its ability to compete with iodinated EGF for binding to EGF membrane receptors. Competing activity is expressed as nanogram equivalents of EGF. Abbreviations: ST, media from ST-FeSV-transformed FRE: 5:2i and BHKi, media from cadmium and zinc-treated 5:2 and BHK cells, respectively; 5:2, media from 5:2 cells. (B) Two-milliliter equivalents of conditioned medium from cells described above were fractionated on a Bio-Sil TSK-250 high-pressure liquid chromatography column $(21.5 \mathrm{by} 600 \mathrm{~cm})$ equilibrated in $40 \%$ acetonitrile- $0.1 \%$ TFA, (pH 1.9). Fractions collected were lyophilized and tested for EGF-competing activity. Arrows denote eluting positions of the marker proteins: $68 \mathrm{~K}$, bovine serum albumin; $14 \mathrm{~K}$, RNase $\mathrm{A} ; 6 \mathrm{~K}$, insulin.

species to one of $M_{\mathrm{r}} 13,000$ to 17,000 . After a 160 -min chase, the detected TGF $\alpha$ precursor species comigrated with the precursor immunoprecipitated from induced 5:2 cells labeled for $8 \mathrm{~h}$ (control lane), suggesting that complete processing had occurred over this 160 -min chase period. The half-life of the precursor identified with anti-TGF $\alpha_{137-159}$ was approximately $2 \mathrm{~h}$. We cannot rule out the possibility that this apparent half-life is due to an early cleavage event involving the carboxy-terminal epitopes used for immunoidentification.

The TGFa precursor protein is membrane associated. The membrane localization of the TGF $\alpha$ precursor was determined by cell fractionation and differential centrifugation.

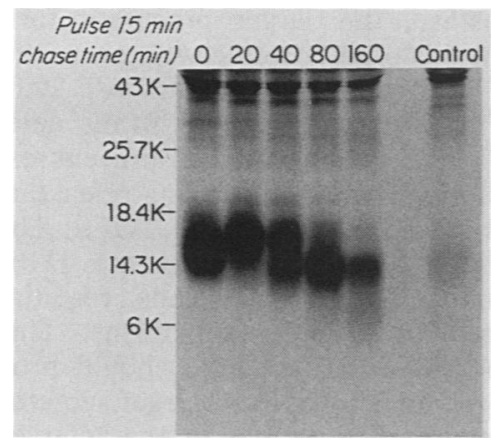

FIG. 5. Pulse-chase analysis of the TGF $\alpha$ precursor protein. The $5: 2$ cells were induced for $10 \mathrm{~h}$ with cadmium and zinc, incubated in cysteine-free media for $1 \mathrm{~h}$, and pulse-labeled with $1 \mathrm{mCi}$ of $\left.{ }^{35} \mathrm{~S}\right]$ cysteine per $\mathrm{ml}$ for $15 \mathrm{~min}$. After pulse-labeling, cells were incubated with complete Dulbecco modified Eagle medium for various times, the TGF $\alpha$ precursor was immunoprecipitated, and immunoprecipitates were fractionated on a $15 \%$ polyacrylamide gel. Molecular weight markers (kilodaltons) are included on the left-hand side of the figure. Only the bottom two-thirds of the gel is shown.
Radiolabeled 5:2 cells treated with cadmium and zinc were broken, and the microsomal fraction and soluble constituents were separated by ultracentrifugation. Both the $S 100$ and P100 fractions from a $100,000 \times g$ centrifugation were tested by immunoprecipitation. The results are shown in Fig.

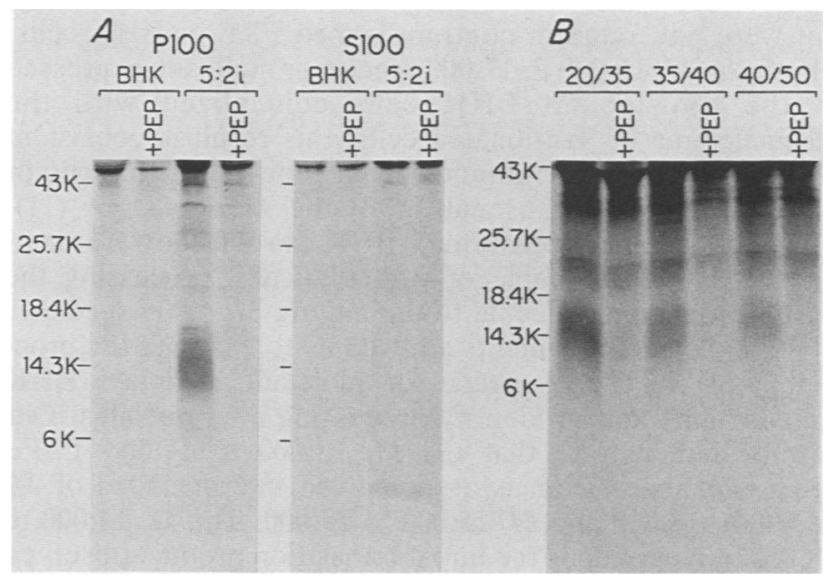

FIG. 6. (A) Microsomal fractionation of the expressed TGFa precursor protein. The BHK and 5:2 cells were treated with cadmium and zinc for $8 \mathrm{~h}$ and labeled with $\left[{ }^{35} \mathrm{~S}\right]$ cysteine for $12 \mathrm{~h}$. The P100 and S100 fractions prepared as described in Materials and Methods were immunoprecipitated with anti-TGF $\alpha_{137-151}$ and analyzed by gel electrophoresis on 12 to $20 \%$ gradient gels. +PEP indicates samples which were preincubated with synthetic peptide before being subjected to immunoprecipitation analysis. (B) Discontinuous sucrose gradient analysis of the P100 fraction from panel $A$. The sucrose interphases indicated were collected and immunoprecipitated with anti-TGF $\alpha_{137-151}$. +PEP denotes samples blocked with synthetic peptide immunogen prior to immunoprecipitation analysis. The location of protein markers is shown to the left in each panel. Only the bottom two-thirds of the gel is shown. 
6A. Nearly all the immunoreactive TGF $\alpha$ precursor protein was found in the P100 fraction (P100; lanes 5:2i), suggesting a membrane association. To delineate this potential membrane association further, the P100 fraction was separated by discontinuous sucrose gradient centrifugation. In this analysis, the plasma membrane fraction collects at the 20/35\% sucrose interphase, since it possesses the lowest density of the microsomal components. Results of the immunoprecipitation analysis of the gradient fractions are shown in Fig. 6B. Densitometric analysis of the autoradiograph reveals that $52 \%$ of the $M_{\mathrm{r}} 13,000$ to 17,000 immunoreactive TGF $\alpha$ precursor fractionates within the $20 / 35 \%$ sucrose interphase. Marker enzyme analysis shows that $64 \%$ of the membraneassociated 5'-nucleotidase activity (29) is located within this sucrose fraction (data not shown). These results suggest colocalization of the TGF $\alpha$ precursor with the plasmalemma fraction.

\section{DISCUSSION}

In this study, we expressed a transfected cDNA encoding the complete rat TGF $\alpha$ precursor in nontransformed BHK fibroblasts to study the expression and processing of the TGF $\alpha$ molecule. The expressed TGF $\alpha$ precursor protein was identified and characterized by site-specific immunological reagents directed toward peptide epitopes within the carboxy end of the precursor polypeptide. A summary of our results follows. First, the TGF $\alpha$ precursor was readily identified in the transfectant BHK fibroblasts. The most stable from of this protein behaved on SDS-polyacrylamide gels as a diffusely migrating protein with apparent $M_{\mathrm{r}} 13,000$ to 17,000 . This value is consistent with the predicted molecular weight of the precursor molecule. Second, immunoreactive proteins which appear to comigrate with the TGF $\alpha$ precursor detected in the BHK transfectant were found in two cell lines, Leydig testicular tumor and ST-FeSVtransformed FRE cells, known to produce TGF $\alpha$ naturally, but were not found in nontransformed FRE or BHK cells. Third, the $M_{\mathrm{r}} 13,000$ to 17,000 precursor molecule expressed in the transfectant BHK cells colocalized with the plasmalemma of fractionated cells; this result is consistent with a proposed membrane localization of the precursor molecule based on an analysis of the TGF $\alpha$ cDNA (11). Finally, these nontransformed BHK fibroblasts were demonstrated to be capable of proteolytically processing the TGF $\alpha$ precursor molecule to the mature $M_{\mathrm{r}} 6,000$ species.

Pulse-chase experiments allowed us to examine the processing of the TGF $\alpha$ precursor molecule in intact BHK transfectants and to identify processing intermediates. Our results demonstrate that the $M_{\mathrm{r}} 13,000$ to $17,000 \mathrm{TGF} \alpha$ precursor arises from two short-lived intermediates of $M_{\mathrm{r}}$ 14,000 to 18,000 and $M_{\mathrm{r}} 15,000$ to 19,000 . The $M_{\mathrm{r}} 14,000$ to 18,000 polypeptide is the initial translation product observed after a short pulse-label and is rapidly converted into the larger, $M_{\mathrm{r}} 15,000$ to 19,000 , intermediate. This initial processing event, which results in the apparent increase in molecular weight observed on SDS-polyacrylamide gels, may be the result of covalent posttranslational modification such as phosphorylation, lipidation, or carbohydrate addition. A typical N-linked glycosylation site is present in the predicted sequence of the TGF $\alpha$ precursor (11). The $M_{\mathrm{r}}$ 15,000 to $19,000 \mathrm{TGF} \alpha$ precursor intermediate is subsequently converted into the $M_{\mathrm{r}} 13,000$ to 17,000 polypeptide. This final precursor form detected by the antipeptide antibodies comigrates with the TGF $\alpha$ precursor identified in the BHK transfectant labeled with $\left[{ }^{35}\right.$ S $]$ cysteine under normal conditions. The loss in molecular weight of approximately 2,000 from the larger TGF $\alpha$ precursor intermediate is probably due to proteolysis. Antibodies directed toward the carboxy-terminal 7 amino acids of the TGF $\alpha$ precursor (anti-TGF $\alpha_{153-159}$ ) were also able to identify similar processing intermediates (data not shown). Thus, this early stage of proteolytic processing must occur at the amino end of the precursor molecule. A loss in molecular weight of 2,000 would be consistent with cleavage of the 23-amino-acid hydrophobic leader peptide predicted from the sequence of TGF $\alpha$ cDNA (13).

Complete processing of the $M_{\mathrm{r}} 13,000$ to 17,000 TGF $\alpha$ precursor polypeptide into the released $M_{\mathrm{r}} 6,000$ form of TGF $\alpha$ was evident in the supernatants of the transfected BHK fibroblasts. Media conditioned by these cells contained TGF $\alpha$ activity (as measured by EGF competition) which, upon gel permeation chromatography, cofractionated with the fully processed 50-amino-acid TGF $\alpha$ form. Proteolytic cleavage of TGF $\alpha$ from its precursor occurs at Ala-Val-Val sequences and is most probably mediated by a protease having elastase-type specificity $(2,11)$. The ability of nontransformed BHK fibroblasts to completely process the TGF $\alpha$ precursor indicates that these cells do express this protease and suggests that processing is not mediated by a tumor-specific proteolytic enzyme. It is entirely possible, however, that the levels of this protease are elevated in the malignant state. In this regard, it is interesting that while ST-FeSV-transformed FRE cells secrete significantly higher levels of the mature growth factor, they contain significantly lower levels of the $M_{\mathrm{r}} 13,000$ to 17,000 species. This is also true of the Leydig tumor cells (data not shown), suggesting that the half-life of the precursor is considerably shorter in malignant cells than in nontransformed BHK cells.

Several size classes of TGF $\alpha$ have previously been observed in the supernatants and extracts from tumor cells $(1$, 27). Although the $M_{\mathrm{r}} 6,000$ form of TGF $\alpha$ has been well characterized (15), its relationship with the larger forms of TGF $\alpha$ precursor is not well documented. Linsley et al. (12) and Ignotz et al. (8) used antipeptide sera directed toward the carboxy terminus of the 50-amino-acid TGF $\alpha$ molecule to characterize the larger secreted forms. Several molecular weight classes of immunoreactive material were identified, the most conspicuous of which was a polypeptide of molecular weight approximately $20,000(8,12)$. Ignotz et al. extended this analysis further and revealed that after digestion with elastase, this larger precursor form of TGF $\alpha$ released an $M_{\mathrm{r}} 6,000$ polypeptide with properties of mature TGF $\alpha$ (8). The relationship of this $M_{\mathrm{r}} 20,000$ secreted (released) form with the precursor forms detected in this report remains to be established. Our present results indicate that nontransformed BHK fibroblasts release only the mature, fully processed 50 -amino-acid TGF $\alpha$. This raises the possibility that tumor cells process the TGF $\alpha$ precursor differently from nontransformed cells, resulting in the release of larger TGF $\alpha$ precursor forms. The precursorspecific antibodies described here should prove useful in assessing the relationship of these larger secreted forms with the TGF $\alpha$ precursor, as well as in characterizing the highmolecular-weight forms of TGF $\alpha$-like species previously found in the urine of patients with disseminated cancer (21, 25).

Although much is known concerning the biological properties of TGF $\alpha$, the role of this growth factor in the development of the malignant state remains unclear. The production of TGF $\alpha$ by a variety of transformed cells (24; Twardzik and Ranchalis, in press), as well as its occurrence in the 
urine of cancer patients $(21,25)$, implies that it plays an important role in cellular transformation. Recently, Rosenthal et al. (19) presented evidence that the expression of the TGF $\alpha$ gene in nontransformed Rat-1 cells results in the acquisition of the transformed phenotype via an autocrine mechanism. Although we have not yet examined in detail the phenotype of the TGF $\alpha$-expressing BHK cells, the precursor-processing capability of these nontransformed fibroblasts represents the initial stage of an autocrine response (22). We are currently examining the phenotype of these cells.

\section{ACKNOWLEDGMENTS}

We are grateful to Richard Palmiter and Greg Mundy for cells, to Peter Linsley and Hans Marquardt for helpful discussions and critical comments, and to Nancy Olfs and Craig English for preparation of the manuscript.

This work was partially supported by Public Health Service grant CA 43793 to D.C.L. from the National Institutes of Health.

\section{ADDENDUM IN PROOF}

While this manuscript was in press, Bringman et al. (T. S. Bringman, P. B. Lindquist, and R. Derynk, Cell 48:429-440, 1987) presented similar evidence describing the processing of the TGF $\alpha$ precursor.

\section{LITERATURE CITED}

1. De Larco, J. E., and G. J. Todaro. 1978. Growth factors from murine sarcoma virus-transformed cells. Proc. Natl. Acad. Sci. USA 75:4001-4005.

2. Derynck, R., A. B. Roberts, M. E. Winkler, E. Y. Chen, and D. V. Goeddel. 1984. Human transforming growth factor- $\alpha$ : precursor structure and expression in E. coli. Cell 38:287-297.

3. Gentry, L. E., and A. Lawton. 1986. Characterization of sitespecific antibodies to the erbB gene product and EGF receptor: inhibition of tyrosine kinase activity. Virology 152:421-431.

4. Gentry, L. E., L. R. Rohrschneider, J. E. Casnellie, and E. G. Krebs. 1983. Antibodies to a defined region of $p 0^{\mathrm{src}}$ neutralize tyrosine-specific kinase activity. J. Biol. Chem. 258:1121911228.

5. Glisin, V., R. Crkvenjakov, and C. Byus. 1974. Ribonucleic acid isolated by cesium chloride centrifugation. Biochemistry 13:2633-2638.

6. Ibbotson, K. J., J. Harrod, M. Gowen, S. D'Souza, M. E. Winkler, R. Derynck, and G. R. Mundy. 1986. The effects of recombinant human transforming growth factor- $\alpha$ on bone resorption and formation in vitro. Proc. Natl. Acad. Sci. USA 83:2228-2232.

7. Ibbotson, K. J., D. R. Twardzik, S. M. D'Souza, W. R. Hargreaves, G. J. Todaro, and G. R. Mundy. 1985. Stimulation of bone resorption in vitro by synthetic transforming growth factor alpha. Science 228:1007-1009.

8. Ignotz, R. A., B. Kelly, R. J. Davis, and J. Massague. 1986. Biologically active precursor for transforming growth factor $\alpha$ released by retrovirally transformed cells. Proc. Natl. Acad. Sci. USA 83:6307-6311.

9. Laemmli, U. K. 1970. Cleavage of structural proteins during the assembly of the head of bacteriophage T4. Nature (London) 227:680-685.

10. Lee, D. C., R. Rochford, G. J. Todaro, and L. P. Villarreal. 1985. Development expression of rat transforming growth factor- $\alpha$ mRNA. Mol. Cell. Biol. 5:3644-3646.

11. Lee, D. C., T. M. Rose, N. R. Webb, and G. J. Todaro. 1985. Cloning and sequence analysis of a cDNA for rat transforming growth factor- $\alpha$. Nature (London) 313:489-491.

12. Linsley, P. S., W. R. Hargreaves, D. R. Twardzik, and G. J. Todaro. 1985. Detection of larger polypeptides structurally and functionally related to type 1 transforming growth factor. Proc. Natl. Acad. Sci. USA 82:356-360.

13. Low, M. J., R. E. Hammer, R. H. Goodman, J. F. Habener, R. D. Palmiter, and R. L. Brinster. 1985. Tissue-specific posttranslational processing of pre-prosomatostatin encoded by a metallothionein-somatostatin fusion gene in transgenic mice. Cell 41:211-219.

14. Manger, R., S. Rasheed, and L. Rohrschneider. 1986. Localiza-

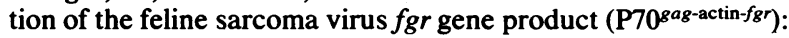
association with the plasma membrane and detergent-insoluble matrix. J. Virol. 59:66-72.

15. Marquardt, H., M. W. Hunkapiller, L. E. Hood, and G. J. Todaro. 1984. Rat transforming growth factor type 1: structure and relation to epeidermal growth factor. Science 223:1079 1082.

16. Marquardt, H., M. W. Hunkapiller, L. E. Hood, D. R. Twardzik, J. E. De Larco, J. R. Stephenson, and G. J. Todaro. 1983. Transforming growth factors produced by retrovirustransformed rodent fibroblasts and human melanoma cells: amino acid sequence homology with epidermal growth factor. Proc. Natl. Acad. Sci. USA 80:4684-4688.

17. Pike, L. J., H. Marquardt, G. J. Todaro, B. Gallis, J. E. Casnellie, P. Bornstein, and E. G. Krebs. 1982. Transforming growth factor and epidermal growth factor stimulate the phosphorylation of a synthetic, tyrosine-containing peptide in a similar manner. J. Biol. Chem. 257:14628-14631.

18. Reynolds, F. H., Jr., G. J. Todaro, C. Fryling, and J. R. Stephenson. 1981. Human transforming growth factors (TGFs) induce tyrosine phosphorylation of EGF receptors. Nature (London) 292:259-262.

19. Rosenthal, A., P. B. Lindquist, T. S. Bringman, D. V. Goeddel, and R. Derynck. 1986. Expression in rat fibroblasts of a human transforming growth factor $\alpha$ cDNA results in transformation. Cell 46:301-309.

20. Schreiber, A. B., M. E. Wendler, and R. Derynck. 1986. Transforming growth factor- $\alpha$ is a more potent angiongenic mediator than epidermal growth factor. Science 232:1250-1253.

21. Sherwin, S. A., D. R. Twardzik, W. H. Bohn, K. D. Cockley, and G. J. Todaro. 1983. High molecular weight transforming growth factor activity in the urine of patients with disseminated cancer. Cancer Res. 43:403-407.

22. Sporn, M. B., and G. J. Todaro. 1986. Autocrine secretion and malignant transforming of cells. N. Engl. J. Med. 303:878-880.

23. Todaro, G. J., C. Fryling, and J. E. De Larco. 1980. Transforming growth factors produced by certain human tumors: polypeptides that interact with epidermal growth factor receptors. Proc. Natl. Acad. Sci. USA 77:5258-5262.

24. Todaro, G. J., H. Marquardt, D. R. Twardzik, F. H. Reynolds, Jr., and J. R. Stephenson. 1985. Transforming growth factors produced by viral transformed and human tumor cells, $p$. 165-182. In E. Mihictz (ed.), Biological responses in cancer: progress toward potential applications, vol. 2. Plenum Publishing Corp., New York.

25. Twardzik, D. R., S. A. Sherwin, J. E. Ranchalis, and G. J. Todaro. 1982. Transforming growth factors in the urine of normal, pregnant and tumor-bearing humans. JNCI 69:793-798.

26. Twardzik, D. R., G. J. Todaro, H. Marquardt, F. H. Reynolds, Jr., and J. R. Stephenson. 1982. Abelson MuLV induced transformation growth factors (TGFs) produced by cells transformed by different isolates of feline sarcoma virus. Science 216: $894-897$.

27. Twardzik, D. R., G. J. Todaro, F. H. Reynolds, Jr., and J. R. Stephenson. 1983. Similar transforming growth factor (TGFs) produced by cells transformed by different isolates of feline sarcoma virus. Virology 124:201-207.

28. Wigler, M., R. Sweet, G. K. Sim, B. Wold, A. Pellicer, E. Lacy, T. Maniatis, S. Silverstein, and R. Axel. 1979. Transformation of mammalian cells with genes from procaryotes and eucaryotes. Cell 16:777-785.

29. Windnell, C. C., and J. C. Unkeless. 1968. Partial purification of a lipoprotein with 5 '-nucleotidase activity from membranes of rat liver cells. Proc. Natl. Acad. Sci. USA 61:1050-1057. 